\title{
Stage III Lip and Oral Cavity Squamous Cell Carcinoma AJCC v6 and v7
}

National Cancer Institute

\section{Source}

National Cancer Institute. Stage III Lip and Oral Cavity Squamous Cell Carcinoma A/CC v6 and v7. NCI Thesaurus. Code C115059.

Stage III includes: (T3, N0, M0); (T1, N1, M0); (T2, N1, M0); (T3, N1, M0). T3: Tumor more than $4 \mathrm{~cm}$ in greatest dimension. $\mathrm{N} 1$ : Metastasis in a single ipsilateral lymph node, $3 \mathrm{~cm}$ or less in greatest dimension. M0: No distant metastasis. (AJCC 6th and 7th eds.) 